\title{
Pendampingan Pengembangan Sistem Informasi Antrian Disabilitas Rumah Sakit Panti Waluyo Purworejo
}

\author{
Danny Sebastian ${ }^{\# 1}$, Kristian Adi Nugraha ${ }^{\# 2}$ \\ ${ }^{\#}$ Fakultas Teknologi Informasi, Universitas Kristen Duta Wacana \\ ${ }^{1}$ danny.sebastian@staff.ukdw.ac.id \\ ²adinugraha@staff.ukdw.ac.id
}

\begin{abstract}
Abstrak: Every patient has the right to receive healthcare service. However, not everyone has equal access to these services. This problem is especially apparent in patients with disabilities. Duta Wacana Christian University's Faculty of Information Technology is working alongside Panti Waluyo Hospital in Purworejo to build a priority queueing system for disabled patients. This system is expected to improve patient admission and queueing process. The proposed system consists of a website and a mobile application which has undergo 6 months of continuous development and online mentorship, starting from January 2020 up until June 2020.
\end{abstract}

Keyword: hospital, disability, patient with disability, priority queue

\begin{abstract}
Abstrak: Setiap pasien memiliki hak untuk mendapatkan pelayanan kesehatan. Sayangnya, tidak semua pasien dapat mendapatkan akses pelayanan kesehatan secara mudah. Tidak jarang, pasien disabilitas merasa kesulitan dalam mendapatkan akses pelayanan kesehatan. Fakultas Teknologi Informasi Universitas Kristen Duta Wacana bekerja sama dengan Rumah Sakit Panti Waluyo Purworejo untuk membangun sebuah sistem antrian prioritas bagi para pasien penyandang disabilitas. Sistem ini diharapkan dapat membantu proses pendaftaran pemeriksaan dan antrian poliklinik. Sistem ini sendiri terdiri dari aplikasi website dan aplikasi mobile dengan kegiatan pengembangan dan pendampingan selama 6 bulan, dimulai dari bulan Januari 2020 sampai Juni 2020 dan dilakukan secara daring.
\end{abstract}

Kata kunci: rumah sakit, pasien disabilitas, antrian prioritas

\section{PENDAHULUAN}

Salah satu penerapan teknologi informasi pada bidang kesehatan adalah Sistem Informasi Manajemen Rumah Sakit (SIMRS). SIMRS adalah sebuah sistem informasi yang dirancang secara khusus untuk membantu pengelolaan dan perencanaan program kesehatan pada sebuah rumah sakit (Setyawan, 2016). Penggunaan SIMRS mencakup setiap proses yang ada di rumah sakit. Dengan menggunakan SIMRS sebagai bentuk penerapan teknologi informasi, pengolahan data akan menjadi lebih efektif dan efisien (Hakam, Nugroho, \& Meliala, 2017). SIMRS harus mencakup data transaksi (medis, non-medis, dan penunjang medis) yang memudahkan dan meningkatkan pelayanan di rumah sakit (Odelia, 2018) (Nugraha, Sebastian, \& Rini, 2020). Kemudahan layanan ini harus dinikmati oleh semua kalangan pasien, tidak terkecuali pasien yang memiliki kebutuhan 
khusus/penyandang disabilitas.

Penyandang disabilitas adalah orang yang memiliki keterbatasan fisik, mental, intelektual atau sensorik dalam jangka waktu lama yang dalam berinteraksi dengan lingkungan dan sikap masyarakatnya dapat menemui hambatan yang menyulitkan untuk berpartisipasi penuh dan efektif berdasarkan kesamaan hak (Undang-Undang Nomor 19 Tahun 2011 Tentang Pengesahan Hak-Hak Penyandang Disabilitas). Penyandang disabilitas memiliki hak-hak yang sama seperti masyarakat pada umumnya untuk penggunaan fasilitas umum, termasuk aksesibilitas terhadap layanan kesehatan di rumah sakit. Rumah sakit adalah badan yang memberikan layanan kesehatan pada masyarakat umum, termasuk di dalamnya adalah penyandang disabilitas. UndangUndang nomor 8 tahun 2016 Pasal 12 menyatakan bahwa Penyandang Disabilitas berhak mendapatkan layanan kesehatan yang setara dengan masyarakat pada umum dengan berhak memperoleh kesetaraan informasi, kesetaraan akses atas Sumber daya, kesetaraan pelayanan kesehatan, kesetaraan dalam menentukan secara mandiri layanan kesehatan yang diperlukan, memperoleh Alat Bantu Kesehatan sesuai kekurangannya, dan memperoleh obat dengan efek samping rendah.

Masyarakat dengan kebutuhan khusus/penyandang disabilitas secara signifikan membutuhkan perlakuan khusus karena adanya keterbatasan pada kondisi fisik agar dapat menggunakan fasilitas umum seperti masyarakat pada umumnya. Yang termasuk dalam masyarakat dengan kebutuhan khusus antara lain tuna netra, tuna rungu, tuna daksa, anak dengan kecerdasan luar biasa, tuna grahita, lamban belajar, anak dengan kesulitan belajar spesifik, gangguna komunikasi, tuna laras, dan autisme (Harthanti, Tani, \& Syamsiar, 2015). Pemenuhan HAM bagi penyandang disabilitas seharusnya menjadi prioritas utama bagi penyedia layanan kepada masyarakat (Lestari, Sumarto, \& Isdaryanto, 2017).

Secara umum, bentuk antrian ada 3, yaitu yang datang pertama akan dilayani pertama (First Come First Serve/FIFO), antrian secara acak (Service in Random Order/SIRO), dan pelanggan yang datang terakhir dilayani pertama (Late Come First Serve/LIFO) (Ni'amah \& Sugito, 2011). Selain ketiga model tersebut, ada juga antrian prioritas. Bentuk penerapan antrian prioritas pada layanan Rumah sakit adalah pada Unit Gawat Darurat (UGD). Prioritas lebih tinggi diberikan kepada pasien yang memiliki urgensitas tinggi, seperti memiliki penyakit yang menjadi lebih parah apabila tidak dilayani terlebih dahulu.

Rumah sakit Panti Waluyo Purworejo bekerja sama dengan Fakultas 
Teknologi Informasi Universitas Kristen

Duta Wacana (FTI UKDW) memiliki visi dan keinginan untuk memberikan pelayanan yang terbaik bagi masyarakat luas. Salah satu misi dari Rumah sakit Panti Waluyo Purworejo adalah memberikan layanan kepada pasien penyandang disabilitas. Saat ini masih belum ada pembeda antara pasien penyandang disabilitas dengan pasien biasa. Tim Rumah Sakit Panti Waluyo bekerjasama dengan FTI UKDW untuk membuat aplikasi antrian prioritas bagi pasien dengan kebutuhan khusus/penyandang disabilitas. Aplikasi yang dibangun diharapkan dapat menjadi layanan pertama yang pemprioritaskan pasien penyandang disabilitas di Rumah Sakit Panti Waluyo Purworejo.

\section{RUMUSAN MASALAH}

\section{A. Rumusan Masalah}

Rumusan masalah yang ingin diselesaikan melalui kegiatan ini adalah bagaimana meningkatkan mutu layanan kesehatan bagi pasien penyandang disabilitas yang saat ini masih memiliki kendala dengan cara memanfaatkan Teknologi Informasi dan Komunikasi, khususnya pada layanan pendaftaran dan antrian.

\section{B. Tujuan}

Tujuan dari kegiatan iBM ini adalah untuk membuat aplikasi antrian prioritas bagi penyandang disabilitas berbasis website dan melakukan pendampingan pembelajaran kepada penyandang disabilitas untuk mendapatkan pelayanan secara mandiri. Selain itu melakukan pendampingan kepada Rumah Sakit Panti Waluyo Purworejo dalam menerapkan aplikasi yang sudah dibangun.

\section{Manfaat}

Manfaat yang diperoleh dari kegiatan pelatihan ini antara lain:

- Meningkatkan kemampuan para penyandang disabilitas di bidang pemanfaatan Teknologi Informasi dan Komunikasi

- Meningkatkan mutu layanan kesehatan khususnya bagi para penyandang disabilitas di Rumah Sakit Panti Waluyo Purworejo

- Meningkatkan produktivitas petugas fasilitas layanan kesehatan dengan adanya antrian prioritas.

- Menjadi salah satu realisasi kerjasama yang dibangun antara Rumah Sakit Panti Waluyo Purworejo dengan FTI UKDW 


\section{METODE PENGABDIAN}

Tim Pengabdian ini terdiri dari 2 orang dosen, yaitu Danny Sebastian dan Kristian Adi Nugraha. Danny Sebastian berperan sebagai ketua dalam tim ini, sedangkan Kristian Adi Nugraha sebagai anggota.

Proses pengabdian dilakukan secara rutin kunjungan setiap $1 \mathrm{x} /$ minggu dan koordinasi secara daring menggunakan Whatsapp. Tahap-tahap yang dilakukan dalam kegiatan pengabdian ini adalah sebagai berikut:

\section{Koordinasi dengan mitra}

Langkah awal pengabdian ini dengan berkoordinasi dengan Rumah Sakit Panti Waluyo Purworejo. Koordinasi mencakup pengaturan jadwal pelaksanaan, survey kondisi lapangan, dan survey daftar kebutuhan. Rumah Sakit Panti Waluyo siap bekerjasama dengan tim pengabdian untuk membantu dalam pendaftaran peserta pelatihan, dan koordinasi dengan petugas tempat fasilitas layanan kesehatan.

\section{Perancangan dan Pengembangan} Perangkat Lunak

Aplikasi yang dikembangkan adalah aplikasi berbasis website dengan menggunakan PHP dan aplikasi mobile menggunakan flutter. Perancangan akan menggunakan usecase deskripsi agar dapat mendefinisikan proses secara detil (Sebastian, Nugraha, \& Rini, 2018).

\section{Implementasi dan evaluasi}

Kegiatan implementasi dan evaluasi dilakukan untuk menguji aplikasi pada kondisi nyata di Rumah Sakit Panti Waluyo Purworejo. Pengujian akan dilakukan dengan pasien disabilitas dan pengujian lapangan. Perumusan dan pengujian SOP yang berlaku untuk antrian prioritas bagi pasien penyandang disabilitas.

TABEL I

RENCANA KEGIATAN PENGABDIAN

\begin{tabular}{|c|c|c|}
\hline No. & Kegiatan & Waktu \\
\hline 1 & $\begin{array}{l}\text { Observasi \& wawancara } \\
\text { kebutuhan aplikasi }\end{array}$ & $\begin{array}{c}\text { Februari } \\
2020\end{array}$ \\
\hline 2 & $\begin{array}{l}\text { Perancangan } \& \\
\text { pengembangan perangkat } \\
\text { lunak }\end{array}$ & $\begin{array}{c}\text { Maret- } \\
\text { April } \\
2020\end{array}$ \\
\hline 3 & Implementasi \& Evaluasi & $\begin{array}{l}\text { Mei-Juni } \\
2020\end{array}$ \\
\hline
\end{tabular}

\section{HASIL PEMBAHASAN}

\section{A. Observasi \& Wawancara kebutuhan}

\section{Aplikasi}

Kegiatan pengabdian ini dimulai dengan adanya diskusi antara ketua tim pengabdian, Danny Sebastian dengan tim Pusat Rehabilitasi Yakkum pada awal tahun 2020 di Pusat Rehabilitasi Yakkum, Jln Kaliurang KM. 13,5 Ngaglik, Sleman, 
Daerah Istimewa Yogyakarta. Dari hasil rapat dan diskusi, dihasilkan sebuah keputusan untuk mengembangkan sistem pendaftaran prioritas bagi para penyandang disabilitas bagi seluruh rumah sakit yang berada dibawah naungan Yakkum. Sebagai pilot project ditunjuk Rumah Sakit Panti Waluyo Purworejo. Gambar 1 merupakan kegiatan rapat dengan Yayasan Yakkum.

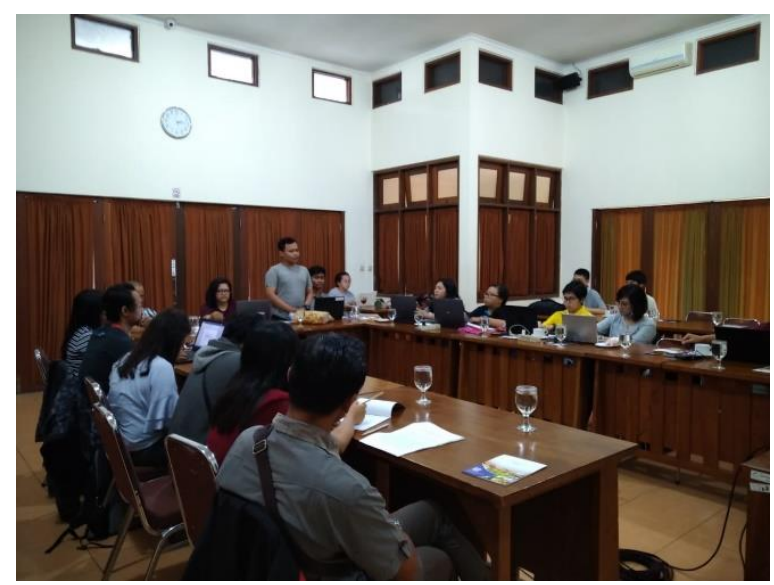

Gambar 1. Rapat dengan Yayasan Yakkum

Secara umum, pasien penyangdang disabilitas yang hendak berobat di Rumah Sakit Panti Waluyo Purworejo. Pasien penyandang disabilitas biasanya kesulitan pada saat pendaftaran dan pada saat menunggu antrian. Pihak Rumah Sakit Panti Waluyo hendak memberikan prioritas lebih tinggi bagi para pasien penyandang disabilitas, tetapi sistem dan prosedur kerja yang berlaku saat ini tidak dapat mengakomodasi hal tersebut. Tim Tekonologi Informasi Rumah Sakit Panti Waluyo Purworejo tidak dapat melakukan modifikasi sistem secara mandiri karena sistem yang digunakan berasal dari Yayasan Yakkum.

Pada tanggal 1 Februari 2020, dr. Regowo, M. Kes selaku direktur dari RS Panti Waluyo Purworejo mengajukan mengajukan permohonan kepada Fakultas Teknologi Informasi Universitas Kristen Duta Wacana untuk memberikan bantuan berupa pendampingan dan pengembangan implementasi sistem informasi antrian yang dapat membantu penyandang disabilitas di Rumah Sakit Panti Waluyo Purworejo.

Kegiatan pertama yang dilakukan oleh penulis adalah melakukan kunjungan ke Rumah Sakit Panti Waluyo Purworejo dan melakukan wawancara awal. Kegiatan ini pada hari Jumat, 7 Februari 2020 untuk membahas apa yang dibutuhkan oleh Rumah Sakit Panti Waluyo Purworejo. Selain itu, tim pelaksana juga melakukan observasi kondisi sistem dan prosedur antrian yang berlaku. Nara sumber pada kegiatan ini adalah Direktur, Komisaris, dan Tim Teknologi Informasi Rumah Sakit Panti Waluyo Purworejo. Gambar 2 merupakan foto saat tim pengabdian melakukan observasi lapangan bersama dengan tim Teknologi Informasi Rumah Sakit Panti Waluyo Purworejo. 


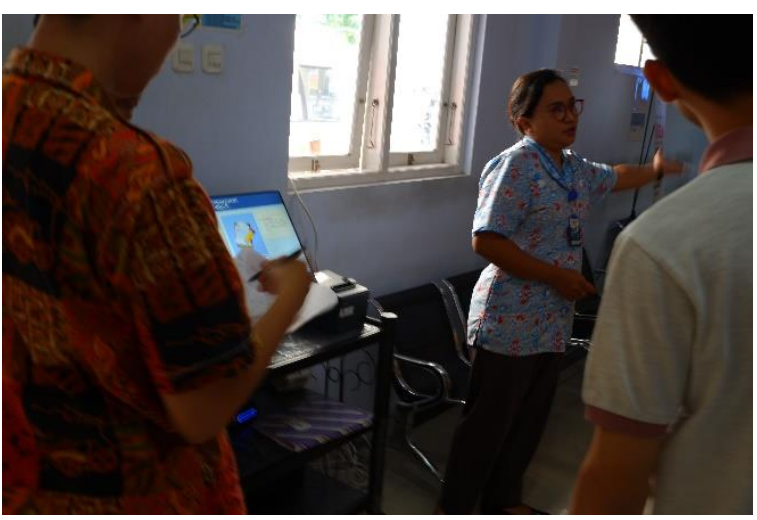

Gambar 2. Kegiatan survey lapangan dan koordinasi dengan mitra.

Gambar 3 merupakan layar dari aplikasi sistem antrian yang digunakan. Antrian terbagi menjadi 3, yaitu antrian A, atrian B dan dan antrian C. Dengan jumlah loket yang digunakan adalah 3 loket. Gambar 4 merupakan foto petugas pendaftaran Rumah Sakit Panti Waluyo yang sedang menjelaskan sistem pendaftaran yang digunakan.

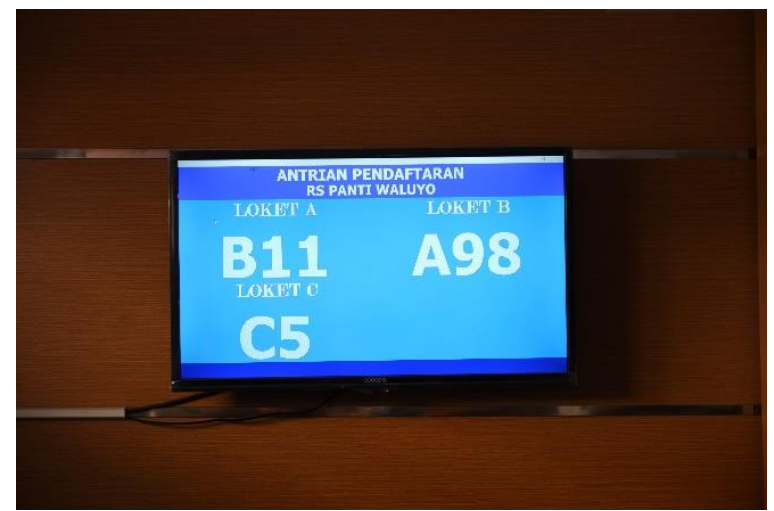

Gambar 3. Layar antrian yang digunakan oleh RS Panti Waluyo saat ini.

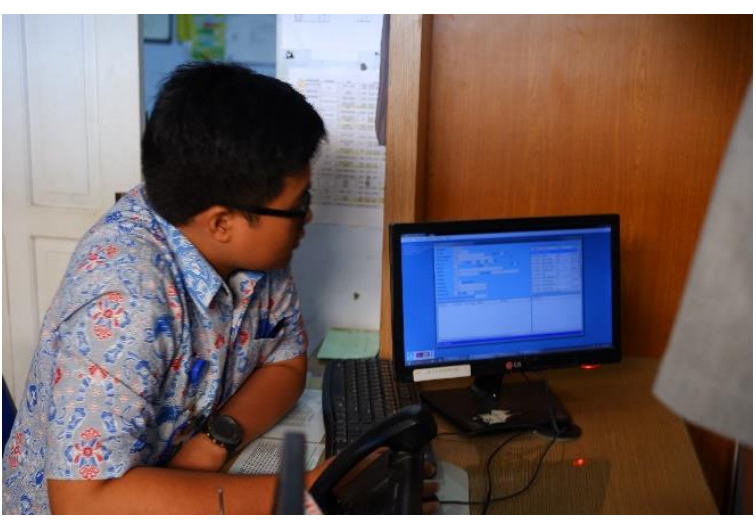

Gambar 4. Penjelasan sistem pendaftaran yang digunakan saat ini.

Tim pengabdian mengumpulkan dan merangkum seluruh informasi yang diperoleh melalui tahap diskusi dan observasi. Langkah selanjutnya, tim pengabdian melakukan Analisa terhadap kemungkinan solusi yang memungkinkan untuk dilakukan, apakah membuat aplikasi baru atau melakukan reverse engineering untuk mengubah kode program aplikasi yang digunakan saat ini. Tim pengabdian memutuskan untuk membuat aplikasi baru yang terpisah dari aplikasi yang digunakan saat ini. Keputusan ini diambil dengan pertimbangan keamanan data karena adanya data yang harus dijadikan sebuah layanan website API yang akan diakses oleh perangkat mobile/handphone milik pasien penyandang disabilitas. Aplikasi website akan dibangun menggunakan Bahasa pemrograman PHP dan aplikasi mobile akan dibangun menggunkan flutter.

Secara umum pada tahap koordinasi disepakati bahwa: 
- Jenis disabilitas tidak mempengaruhi prioritas pendaftaran menggunakan aplikasi ini.

- Aplikasi dibangun terpisah dari SIMRS karena akan diujicoba terlebih dahulu sebelum diintegrasikan ke SIMRS

- Tim pengabdian akan berkunjung secara rutin ke RS Panti Waluyo Purworejo 1x dalam 1 minggu untuk melakukan presentasi progress.

\section{B. Perancagan \& Pengembangan Aplikasi}

Pada tahap perancangan dan pengambangan aplikasi pada kegiatan pengabdian terjadi pandemic Covid-19 yang membatasi pergerakan masyarakat dalam berkomunikasi. Sehingga rencana kunjungan rutin kegiatan pengabdian dibatalkan dan kegiatan pengabdian dilakukan secara daring menggunakan whatsapp dan google meet. Pada tahap perancangan dan pengembangan aplikasi, dilakukan koordinasi internal tim pengabdian secara rutin dengan metode daring.

Hasil dari tahap perancangan dan pengembangan adalah sebuah aplikasi website dan aplikasi mobile. Aplikasi yang dihasilkan masih terpisah dari SIMRS karena masih dalam tahap pengujian. Data yang diisikan ke aplikasi hanya sebagian untuk menghindari double entry dan menghemat waktu. Aplikasi website akan digunakan untuk petugas dalam mengelola system secara umum, sedangkan aplikasi mobile akan digunakan oleh pasien penyandang disabilitas untuk melakukan registrasi dan pendaftaran periksa. Gambar 5 dan Gambar 6 menunjukkan halaman aplikasi website daftar periksa dan daftar dokter ketika diakses oleh petugas rumah sakit.

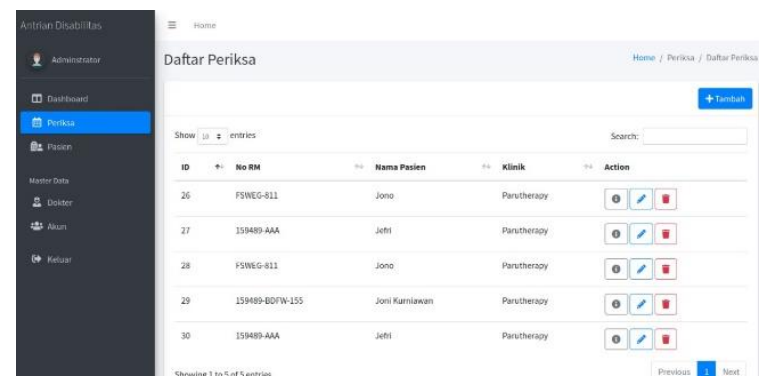

Gambar 5. Halaman website daftar periksa

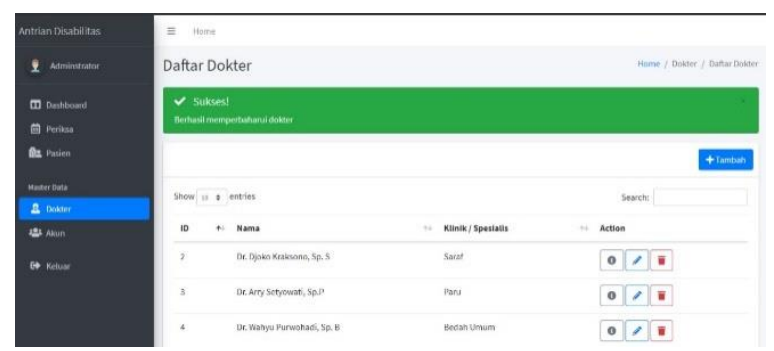

Gambar 6. Halaman website daftar dokter

Gambar 7 menunjukkan salah satu halaman pada aplikasi mobile yang digunakan untuk melihat antrian bagi pasien. Pada halaman ini pengguna aplikasi dapat memeriksa antrian periksa. 


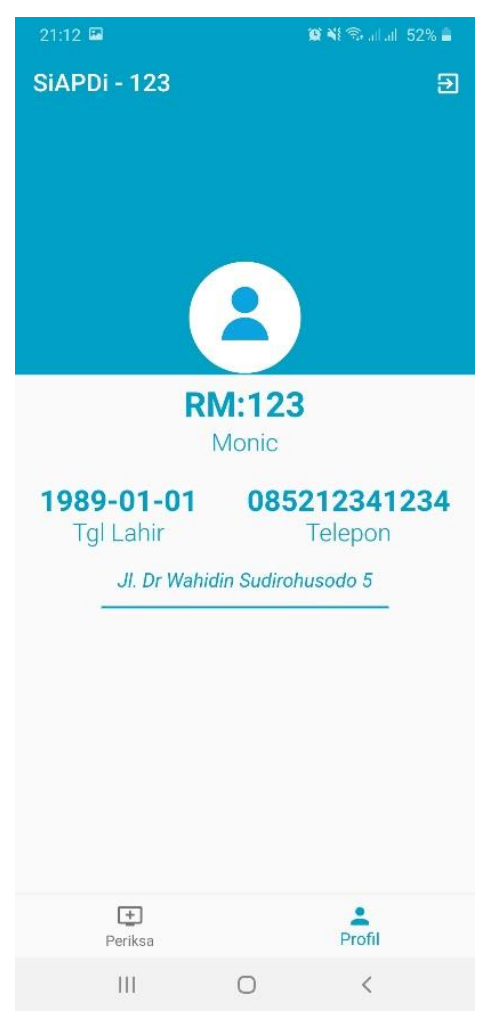

Gambar 7. Halaman aplikasi mobile antrian periksa bagi penyandang disabilitas

\section{Implementasi \& Evaluasi}

Pada bulan Juni 2020 sudah dilakukan evaluasi secara daring menggunakan google meet. Screenshot kegiatan implementasi \& evaluasi menggnakan google meet dapat dilihat pada Gambar 8. Pada tahap ini sistem dianggap sudah layak untuk digunakan, namun terdapat beberapa catatan dan revisi minor, yaitu:

1. Perlu ditambahkan waktu tunggu pada saat pasien melakukan cek antrian, hal ini digunakan untuk mengurangi waktu tunggu dan antrian.

2. Akan dipersiapkan untuk integrasi dengan SIMRS yang digunakan.
3. Aplikasi akan dilanjutkan ke tahap selanjutnya, yaitu integrase dengan SIMRS yang digunakan.

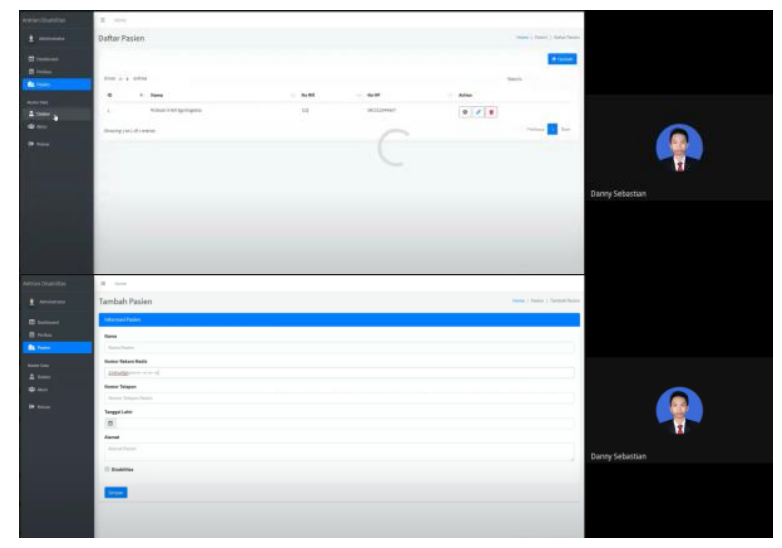

Gambar 8. Kegiatan implementasi dan evaluasi menggunakan google meet

\section{KESIMPULAN}

\section{A. Kesimpulan}

Kesimpulan yang diambil dari kegiatan ini adalah:

1. Kegiatan pendampingan dan pengembangan aplikasi pendaftaran dan antrian prioritas untuk penyandang disabilitas sudah selesai sesuai dengan rencana.

2. Mayoritas kegiatan koordinasi dilakukan secara daring menggunakan google meet dan whatsapp karena adanya pandemic covid-19.

3. Aplikasi yang dibuat dapat mengakomodasi kebutuhan Rumah Sakit Panti Waluyo Purworejo dalam memberikan pelayanan kesehatan bagi pasien penyandang disabilitas. 
4. Kegiatan pengabdian akan dilanjutkan ke tahap 2, yaitu integrase dengan sistem SIMRS.

\section{B. Saran}

Saran untuk kegiatan pengabdian selanjutnya adalah:

1. Perlu adanya integrase sistem sehingga petugas RS tidak melakukan double entry antara aplikasi dengan SIMRS.

2. Dalam berkoordinasi secara daring menggunakan google meet, permasalahan koneksi internet sering terjadi.

\section{UCAPAN TERIMA KASIH}

Penulis mengucapkan terima kasih kepada LPPM UKDW yang telah mendanai kegiatan pengabdian ini dengan surat kontrak nomor 036/D.05/LPPM/2020. Terima kasih juga diucapkan kepada Fakultas Teknologi Informasi Universitas Kristen Duta Wacana dan Rumah Sakit Panti Waluyo Purworejo yang telah mendukung kegiatan pengabdian kepada masyarakat ini.

\section{DAFTAR PUSTAKA}

Hakam, F., Nugroho, E., \& Meliala, A. (2017). Analisis Sistem Dan Teknologi Informasi Sebagai Acauan Dalam Perancangan Rencana Strategis Sistem Informasi Dan Teknologi Informasi (RENSTRA
SI/TI) Di Rumah Sakit Islam Yogyakarta PDHI. JSI: Jurnal Sistem Informasi (E-Journal), 9(1).

Harthanti, D., Tani, L., \& Syamsiar, H. (2015).

STRATEGI PEMBERDAYAAN

MASYARAKAT

INKLUSI BERBASIS KETAHANAN SOSIAL (Studi Kasus di SMP Negeri 04 SelongKabupaten Lombok Timur). Educatio, 10(1), 84-100.

Lestari, E., Sumarto, S., \& Isdaryanto, N. (2017). Pemenuhan hak bagi penyandang disabilitas di kabupaten Semarang melalui implementasi convention on the rights of persons with disabillities (CPRD) dalam bidang pendidikan. Integralistik, 28(1), 1-9.

Ni'amah, D., \& Sugito, S. (2011). SISTEM ANTRIAN DENGAN PRIORITAS PELAYANAN. Prosiding Seminar Nasional Statistika Universitas Diponegoro 2011, (pp. 292-304).

Nugraha, K., Sebastian, D., \& Rini, M. (2020). Pendampingan Penerapan Sistem Informasi pada Pos Kesehatan Paroki Keluarga Kudus Yogyakarta. PATRIA, 2(1), 61-68.

Odelia, E. (2018). Pengembangan Kapasitas Organisasi Melalui Penerapan Sistem Informasi Manajemen Rumah Sakit (SIMRS) Untuk Meningkatkan Mutu 
Patria : Jurnal Pengabdian Kepada Masyarakat

ISSN : 2656-5455 (media online) Vol. 3 | No. 1 Maret 2021

Pelayanan Kesehatan di RSUD dr.

Mohamad Soewandhie Surabaya.

Jurnal Kebijakan Dan Manajemen

Publik, 6(1), 1-8.

Sebastian, D., Nugraha, K., \& Rini, M. (2018). Pendampingan Pembangunan

Aplikasi Penilaian Guru SMA

Kolese De Britto. Prosiding Seminar

Nasional Hasil Pengabdian kepada

Masyarakat (Sendimas 2018). 3, pp.

59-65. Jakarta: Universitas Kristen

Krida Wacana.

Setyawan, D. (2016). Analisis Implementasi

Pemanfaatan Sistem Informasi

Rumah Sakit (SIMRS) Pada RSUD

Kardinah Tegal. Indonesian Journal

on Computer and Information

Technology, 1(2), 54-61. 